\title{
QUATERNARY DEPOSITS IN THE BALTIC SEA WEST OF ESTONIA: PRELIMINARY RESULTS OF A SEISMIC REFLECTION SURVEY
}

\author{
Riko NOORMETS
}

Eesti Teaduste Akadeemia Geoloogia Instituut (Institute of Geology, Estonian Academy of Sciences), Estonia pst. 7, EE-0100 Tallinn, Eesti (Estonia)

Presented by V. Puura

Received May 19, 1993; accepted September 17, 1993

Abstract. The Quaternary deposits of the Baltic Proper west of Estonia have been subdivided by means of continuous seismic reflection profiling. Till, glaciofluvial deposits (sand, gravel), glaciolacustrine and postglacial lacustrine deposits (mainly varved glacial clays), and marine sediments were differentiated.

Pleistocene is represented by tills and glaciofluvial gravel and sand deposits, probably descended from the late stages of the Weichselian glaciation and deposited on a glacially eroded seafloor. Pre-Weichselian till deposits may occur in some deep ancient valleys in the seabed.

The accumulation of glaciolacustrine and postglacial lacustrine silts and clays took place from the beginning of the Baltic Ice Lake Stage to the end of the Ancylus Lake Stage, possibly interrupted by a short period of marine sedimentation during the Yoldia Sea Stage. At present these deposits occur at depths greater than $60 \mathrm{~m}$ but can also be found near the coast under a thin layer of reworked sand.

Since the Litorina Sea Stage marine sedimentation prevails. The accumulation of marine sediments is mostly concentrated to the deep water areas, but their depth distribution is wide. Thus, in the presently studied area, marine sediments occur within the depth interval from 25 to $175 \mathrm{~m}$, although they are mostly found at depths exceeding $70-75 \mathrm{~m}$.

Key words: Quaternary deposits, seismic reflection survey, Baltic Sea.

\section{INTRODUCTION}

Several geophysical methods have been used for scientific marine investigations during the last decades. Of these, the continuous seismic reflection profiling method has proved to be one of the most successful.

The seismic profiling method has been used to investigate the bedrock as well as Quaternary deposits of many parts of the Baltic Sea (Winterhalter, 1972; Axberg, 1980; Axberg et al., 1988; Flodén, 1980; Kjellin et al., 1987; Литвин et al., 1974; Гуделис \& Емельянов, 1976; Гуделис, 1985).

The geological structure of the Gulf of Finland and neighbouring areas west of Estonia has been studied in detail within the framework of a joint study by Estonian and Finnish marine geologists (Раукас \& Хюваринен, 
1992). A review of the geology of the Estonian offshore area has been compiled on the basis of investigations by the Geological Survey of Estonia and the Institute of Geology, Estonian Academy of Sciences (Lutt \& Raukas, 1993). Thus, the scientific works published up till now concern the present area of investigation in a very general way and as part of more extensive territorial investigations.

The present paper, which treats the Baltic Proper west of Hiiumaa and Saaremaa islands from the coast in the east to some $50 \mathrm{~km}$ westwards, is based on approximately $820 \mathrm{~km}$ of seismic reflection profiles obtained from R/V Livonia in 1991.

\section{GENERAL GEOLOGY}

The Baltic Sea underwent several Pleistocene glaciations. The latest, Weichselian, ice sheet started to retreat from the southern parts of the Baltic Sea about 15000 years ago, and from the Gulf of Finland 12000 years ago (Winterhalter et al., 1981). The Weichselian ice eroded almost entirely the deposits of previous glaciations in the central and northern parts of the Baltic Proper. Thus, W of Estonia the till and glaciofluvial deposits descend from the latest part of the Weichselian (Järva) glaciation (Mörner et al., 1977). Somewhat enhanced thicknesses of stratified glacial drift in bedrock valleys and at the base of escarpments may indicate local erosional remnants from previous glaciations.

The development of the Baltic Sea in front of the retreating Weichselian ice sheet has undergone a complicated evolution mainly as a result of the late- and postglacial isostatic rebound. The subdivision of the lateglacial Baltic stages is based on the occasional inflow of salt water from the Atlantic Ocean in the west, i.e. on the successive lake- and sea-stages. Mainly fine-grained material, clay and silt, was deposited W of Estonia during these periods.

Glaciolacustrine and postglacial lacustrine clays were deposited during the period which lasted from the Baltic Ice Lake Stage until the end of the Ancylus Lake Stage, with a possible short interruption during the Yoldia Sea Stage. Marine sediments were later deposited from the beginning of the Litorina Stage to the present. A similar stratigraphic subdivision, based on seismic units in profiling records, has been used for the Gotland area (Axberg et al., 1988).

The bedrock topography and structure are important factors in controlling the distribution and development of the Quaternary deposits. The general isostatic rebound with repeated transgressions and regressions of the sea has greatly affected the formation of the late- and postglacial deposits during the development of the Baltic Sea.

\section{MATERIAL AND METHODS}

The present paper is based on some $820 \mathrm{~km}$ of continuous seismic reflection profiles from the area W of Hiiumaa and Saaremaa islands (Fig. 1). The profiles were obtained during a joint Swedish-Estonian expedition on R/V Livonia in the summer of 1991.

The seismic reflection profiling method is based on the emission of elastic waves by a transmitter in the water and on the recording of the reflections arriving from the boundaries inside a layered rock or sediment sequence (Axberg, 1980; Flodén, 1980; Pegrum, 1989). A general description of the instrumentation used is given in Flodén (1981). 
In the shallow water areas, down to water depths of $50-60 \mathrm{~m}$, some extra information on the uppermost (approximately $30 \mathrm{~m}$ ) bottom deposits was obtained with the SAK-3 equipment, made by marine investigators from Riga, Latvia. The boomer-type transmitter used in SAK-3 equipment (frequency band $2.0-2.8 \mathrm{kHz}$ ) made it possible to obtain detailed information with a vertical resolution of $0.3-0.5 \mathrm{~m}$.

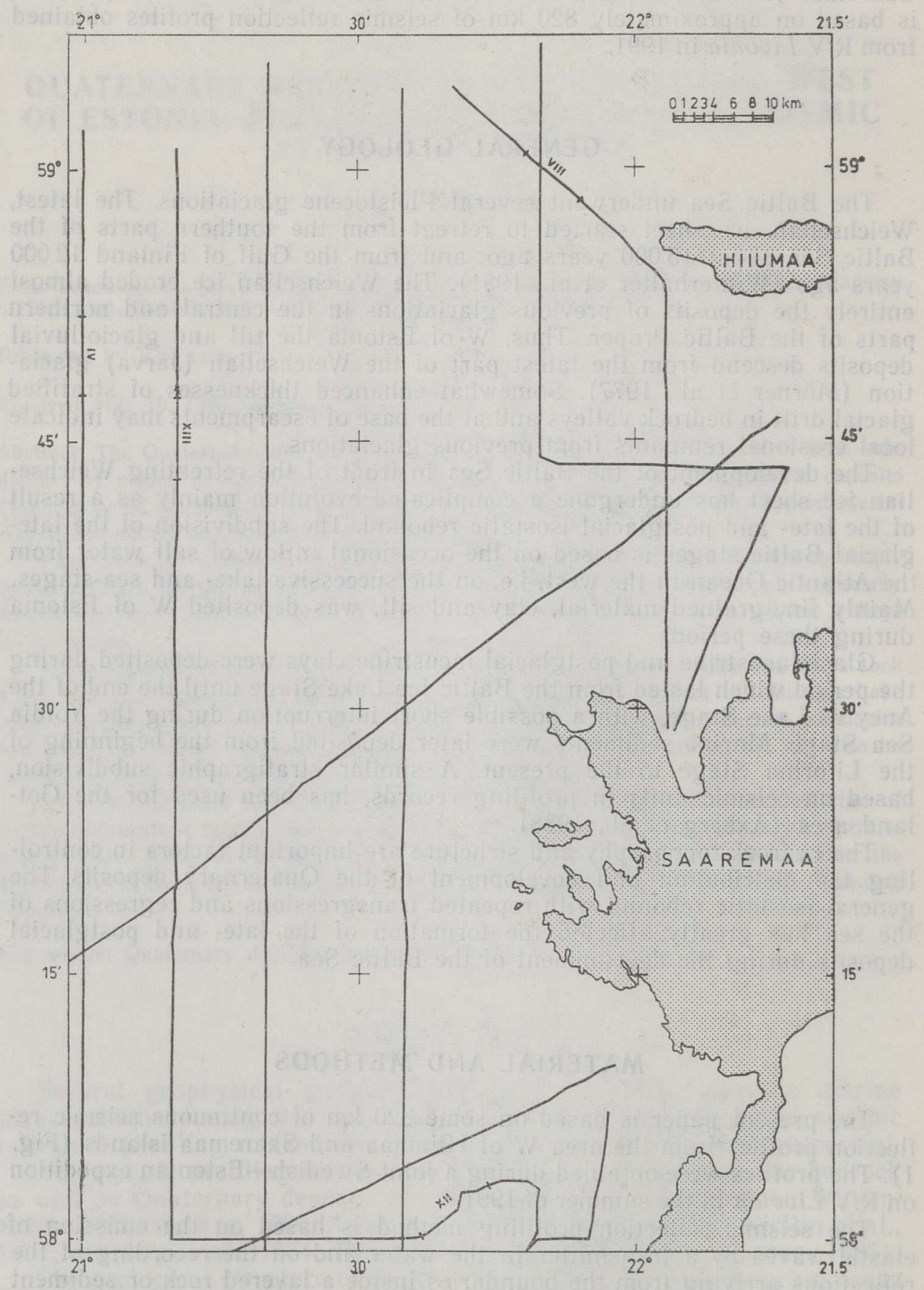

Fig. 1. Area of investigation with the location of continuous seismic reflection profiles. 
In order to interpret the seismic reflection profiles correctly, it is important to be sure in the authenticity of the velocities chosen for the depth calculations. Failure to identify the true velocities may lead to serious misinterpretations of the thicknesses of the deposits. The sound velocities in different types of bottom deposits given by Sviridov (Свиридов, 1977, 1984) have been used in the present paper. According to Sviridov the sound velocity in sea water and marine sediments is approximately $1400 \mathrm{~m} / \mathrm{s}$, in glaciolacustrine and postglacial lacustrine clays $1500 \mathrm{~m} / \mathrm{s}$, and in till and glaciofluvial sands $1690 \mathrm{~m} / \mathrm{s}$. Some other authors (Flodén, 1980; Axberg, 1980) argue that the sound velocities presented by Sviridov are somewhat underestimated. Thus, the mean velocity of the water column in the Gotland area was calculated by Flodén (1980) to be $1440 \mathrm{~m} / \mathrm{s}$.

The vertical scale of the seismic reflection profiles is temporal. In the present profiles, the distance between the horizontal scale lines is $50 \mathrm{~ms}$ (see Fig. 3). The thicknesses of the bottom deposits were calculated considering the vertical time scale and the sound velocities mentioned above. The horizontal scale in the profiles is provided by the positions of the vessel, determined, as a rule, every 20 min and marked by vertical lines on the seismic profiles. This horizontal scale corresponds to approximately $3 \mathrm{~km}$, although the distance depends on the velocity of the vessel. The location of the seismic profiles is given in Fig. 1.

Published methodological recommendations (Литвин et al., 1974; Flodén, 1981; Axberg et al., 1988; Pegrum, 1989) and experiences from investigations of the Quaternary deposits carried out on Estonia's mainland and islands (Раукас, 1978) were taken into consideration in writing this paper.

\section{RESULTS}

On the basis of the available data the following types of Quaternary deposits were differentiated: till, glaciofluvial deposits (sand, gravel), glaciolacustrine and postglacial lacustrine deposits (mainly silts and clays), and marine sediments. The bedrock outcrops, including those areas where the cover of unconsolidated sediments is thinner than the sensitivity of the equipment used, were differentiated as well.

In the northern Baltic Proper areas of sedimentation interact with areas of erosion, and both types of bottoms may be stable or unstable in this respect. Within erosional areas the unconsolidated sediments are continuously carried off by currents and waves, and these areas act as sources of clastic material. Bedrock outcrops occur in stable erosional areas, located prevailingly in the coastal zone at water depths less than $30 \mathrm{~m}$. West of Hiiumaa and Saaremaa islands bedrock outcrops occur mainly on the submarine slopes and in the areas along submarine escarpments, e. g. the Baltic Klint. The boundaries between the areas of exposed bedrock and those of Quaternary deposits are in most cases distinct in the seismic reflection profiles.

Till deposits. Over large areas of erosional seafloor, till is exposed directly on the bedrock. These areas have a typical rugged topography and can therefore easily be differentiated in the seismic profiles. Outcrops of tills are widespread in the southern and eastern parts of the area of investigation, usually near the islands (Fig. 2). Till outcrops are less widespread in the deeper western and north-western parts of the area. Furthermore, the topography of the till is less rugged in these areas. Till outcrops are usually located in areas shallower than $60 \mathrm{~m}$. In deeper areas, till is mostly covered by younger deposits, as is the case for the central parts of the investigated area (Fig. 2). 
Till is the most widely spread type of deposit in the vertical sequence. It makes up morphological formations together with glaciofluvial deposits (Fig. 3). Mapping the distribution of these formations is difficult because of the sparse network of the survey lines. Despite this, it is obvious that there are no extensive and pronounced ice marginal formations within the investigated area.

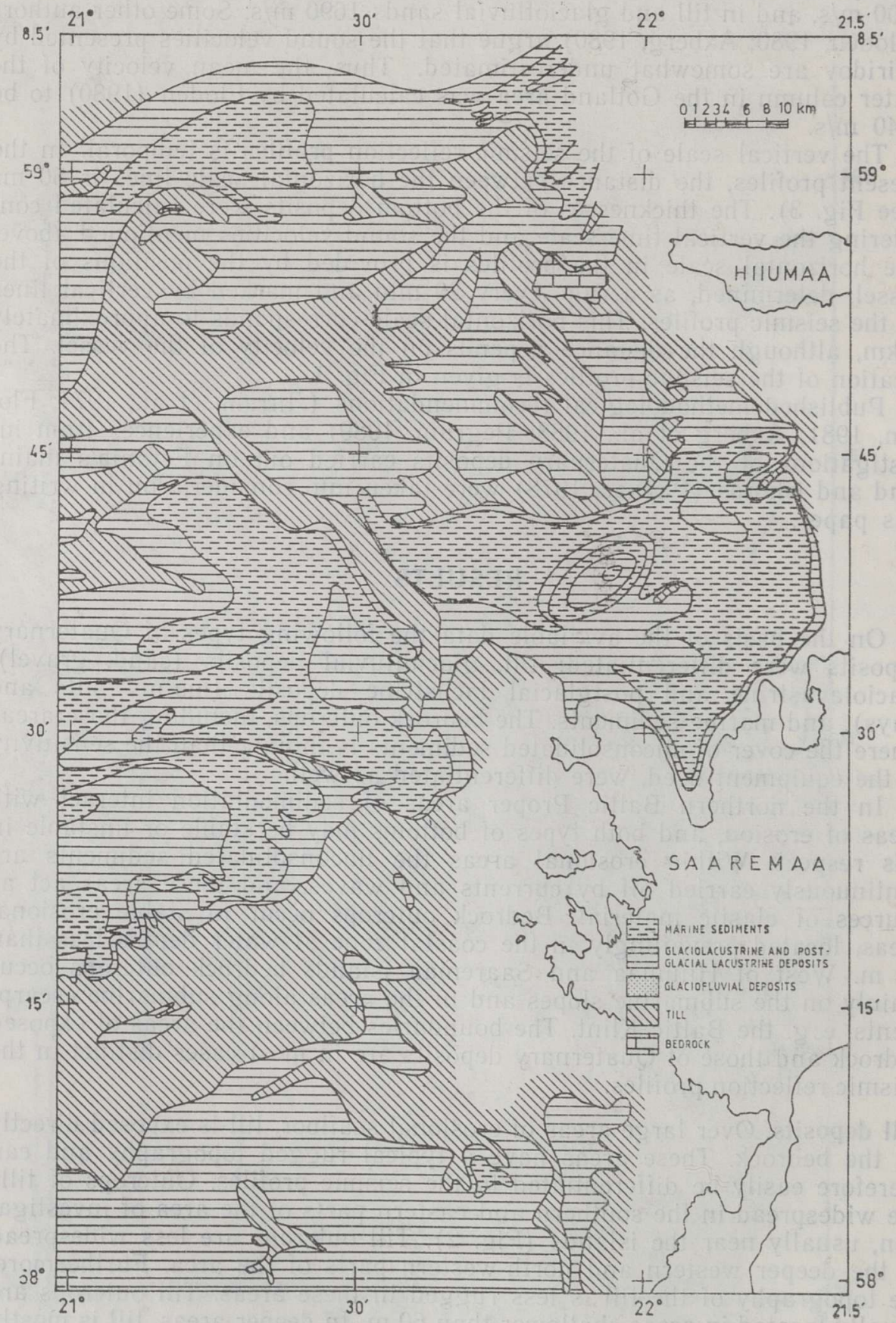

Fig. 2. Map of Quaternary deposits. 


\section{W.1.}

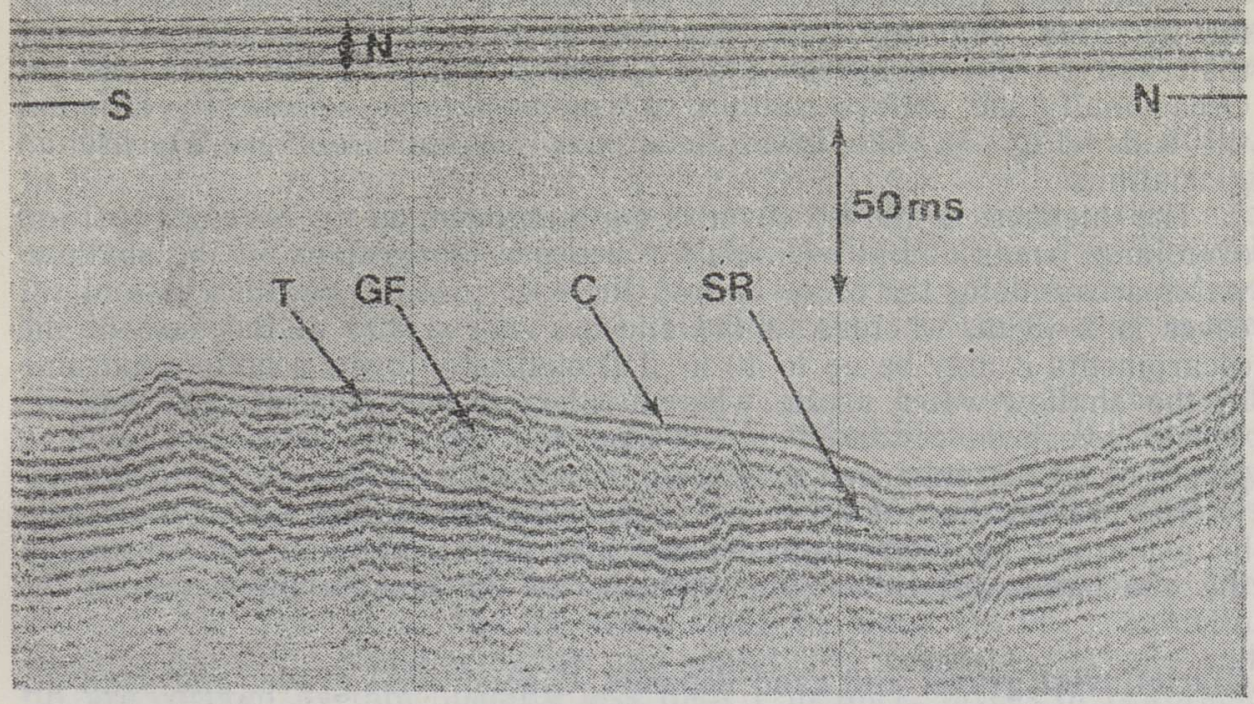

Fig. 3. CSR profile XIII showing the form of bedding common to glaciofluvial deposits; the location of the profiles is given in Fig. 1.

List of seismic marker surfaces: MS - marine sediments; C - glaciolacustrine and postglacial lacustrine deposits; GF - glaciofluvial deposits; T, $\mathrm{T}_{1}, \mathrm{~T}_{2}$-till; SR - sedimentary rock; N-"noise" caused by the technical peculiarity of the equipment. Vertical scale-distance between horizontal lines ( $50 \mathrm{~ms}$ two-way time) corresponds approximately to $35 \mathrm{~m}$ in the sea-water and marine sediments, to $39 \mathrm{~m}$ in the glaciolacustrine and postglacial lacustrine clays, to $44 \mathrm{~m}$ in till and glaciofluvial sands. Horizontal scaledistance between vertical lines ( $20 \mathrm{~min}$ on the average) corresponds approximately to $3 \mathrm{~km}$ in the sea bottom. For the more exact distance see Fig. 1.

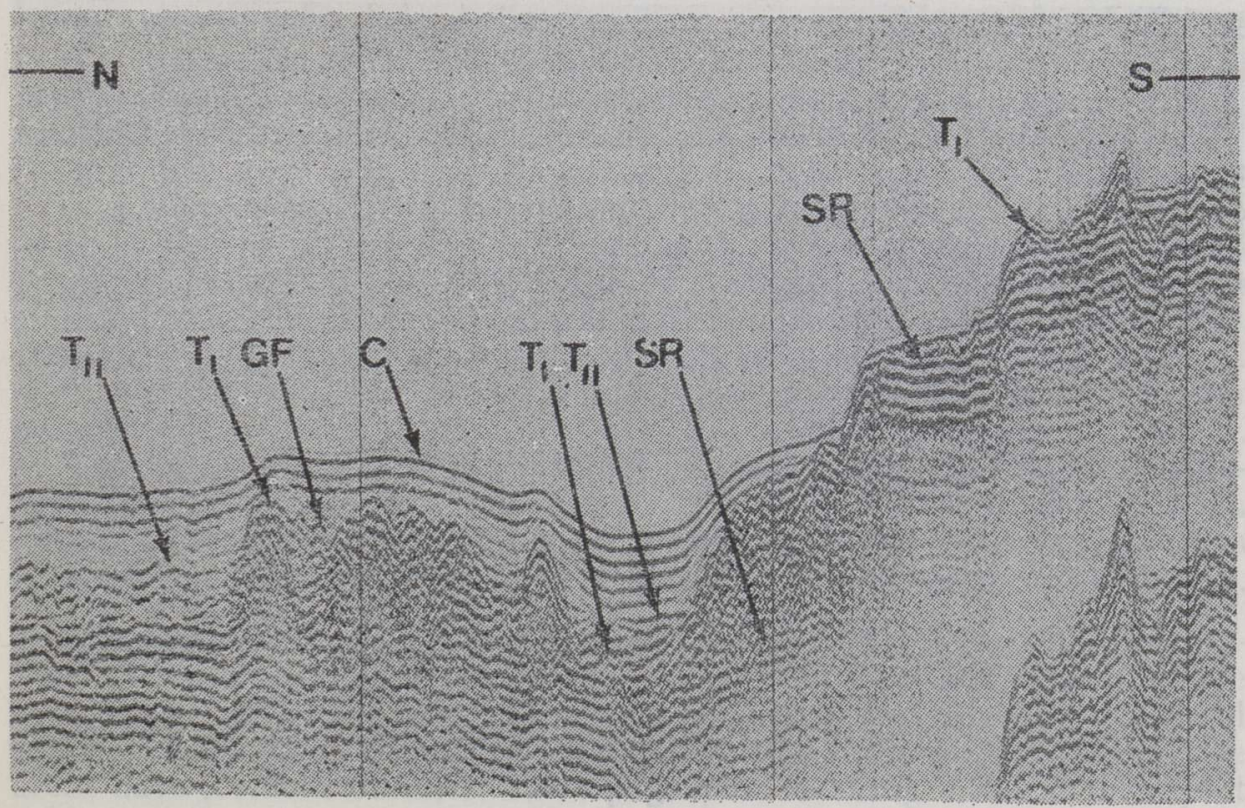

Fig. 4. CSR profile IV presenting the structure of thick cover of till and glaciofluvial deposits on the foot of the escarpment. The list of seismic marker surfaces and the scale are given in Fig. 3. 
In the deep ancient valleys, the till infilling is thicker than the average for the area. Till constitutes together with glaciofluvial deposits more than half of the thickness of the Quaternary deposits in these valleys. Occasionally the valleys contain two or even three seismically different till beds (Fig. 4). The lower beds may descend from pre-Weichselian glaciations.

The thickness of the till cover is quite uniform, on the average $5-15 \mathrm{~m}$ over large areas of flat sedimentary bedrock topography. In the shallowwater areas along the coast and on the escarpments, the thickness of till cover is $2-3 \mathrm{~m}$, whereas in the ancient valleys and at the base of the escarpments it may be up to $40 \mathrm{~m}$. Till obviously forms a bottom moraine in the shallow-water areas, whereas glaciomarine deposits, or deposits which have been reworked and redeposited later by water are found in places of locally enhanced thicknesses of Quaternary deposits (Fig. 4).

The preservation of till deposits in extensive shallow-water areas may be explained by their high density and high resistance to erosion on the one hand and rather low intensity of the erosion processes on the other.

Glaciofluvial gravel and sand deposits. Glaciofluvial gravel and sand deposits are of limited distribution in the investigated area. These deposits are mainly spread at the base of the steep bedrock slopes and in the ancient valleys under till, locally interbedded by till, and sometimes lying on till as well (Fig. 5). The glaciofluvial deposits often occur in the form of ridges of different shapes and sizes. They may have formed as ice marginal formations accumulated, possibly, during oscillations of the ice sheet (Fig. 3).

The resolution in the present seismic reflection profiles does not permit a firm differentiation of the sand and gravel deposits. Thus, they may occupy

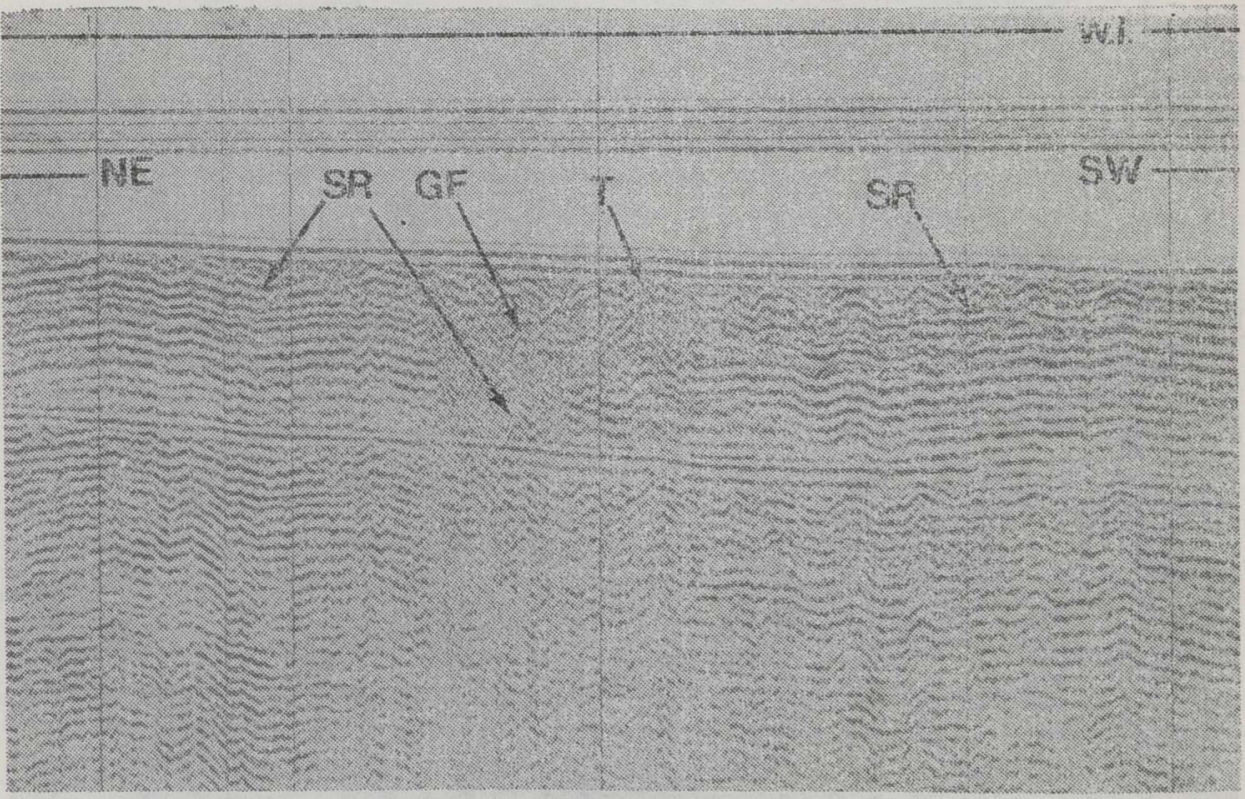

Fig. 5. CSR profile XII. Deep bedrock valley filled mostly by glaciofluvial deposits. The list of seismic marker surfaces and the scale are given in Fig. 3. 
a somewhat greater part of the stratigraphic sequence of unconsolidated sediments than indicated in the present profiles (Figs. 4, 5). The boundary between sand and till is often vague in the seismic profiles, whereas the boundary between sand and bedrock is usually distinct (Fig. 5).

The glaciofluvial deposits reach their greatest thicknesses, up to $25 \mathrm{~m}$, in the bedrock valleys, where sand and gravel have a levelling effect on the topography. As mentioned above, the till cover is thicker than the average for the area within these valleys. The thickness of sand and gravel is somewhat smaller (about $15 \mathrm{~m}$ ) at the base of the escarpments and on the slopes of the bedrock elevations. The till cover is thicker also in the areas of thicker glaciofluvial deposits.

The average thickness of glaciofluvial deposits is $10 \mathrm{~m}$. As the sand and gravel deposits are not always clearly differentiated on the seismic profiles, and as tills of different compositions are interbedded by sandy glaciomarine or glaciofluvial deposits, the thickness of glacial deposits consisting mainly of till can reach $50 \mathrm{~m}$ in some locations.

Sand and gravel deposits have generally no extensive outcrops on the seafloor. The shoal areas and the areas along the coast are the exceptions. In these areas the glaciolacustrine and postglacial lacustrine deposits and till are covered by thin, usually less than $1 \mathrm{~m}$ thick, layers of reworked sand.

Glaciolacustrine and postglacial lacustrine deposits. Glaciolacustrine and postglacial lacustrine deposits are almost as widely spread as till. The cover of glaciolacustrine and postglacial lacustrine clays has been eroded over extensive areas, however. Erosion of these clay deposits was possibly caused by the fluctuations in sea level during Preboreal time (Лутт, 1985). As a consequence, these deposits are spread in the form of fields of very different sizes and shapes on the seafloor. Extensive fields are present in the southern part of the investigated area (Fig. 2).

The cover of the glaciolacustrine and postglacial lacustrine clays is rather uniform, $5-15 \mathrm{~m}$, over the areas with a flat sedimentary bedrock topography (Fig. 5).

The glaciolacustrine and postglacial lacustrine clays occur usually at depths exceeding $60 \mathrm{~m}$. The cover becomes thinner, and is often even lacking, on the escarpments and on the steep slopes of the ancient topography. Despite this, these clay deposits are very common in the coastal areas, as e. g. in Väinameri (Лутт, 1985), and they are usually covered by a thin layer of marine sediments. The cover of glaciolacustrine and postglacial lacustrine clays is rather thick (up to $35 \mathrm{~m}$ ) at the base of the escarpments and in the deep bedrock valleys where they constitute in places more than $1 / 3$ of the total thickness of the unconsolidated deposits. In the areas of thick clay deposits (Fig. 6), it is quite clear that the glaciolacustrine and postglacial lacustrine deposits act as "basin fill" (Winterhalter, 1975).

The outcrop areas of glaciolacustrine and postglacial lacustrine deposits are often quite unstable as to sedimentation and erosion. Thus, in those areas where the sediments are deposited under unstable bottom current conditions, they can be carried away when the conditions change.

Marine deposits. Marine deposits are spread in areas of stable sedimentation: at the base of the escarpments and in the deep central part of the investigated area (Fig. 2). The marine sediments are normally deposited on top of the glaciolacustrine and postglacial lacustrine clays and the areas have tortuous outlines. The topographic levelling effect of the recent marine sediments appears to be even more expressive than that of the lacustrine clays, but the thickness of the marine deposits is smaller and, as a rule, does not exceed $1 / 4$ of the total thickness of the Quaternary deposits (Fig. 6). 


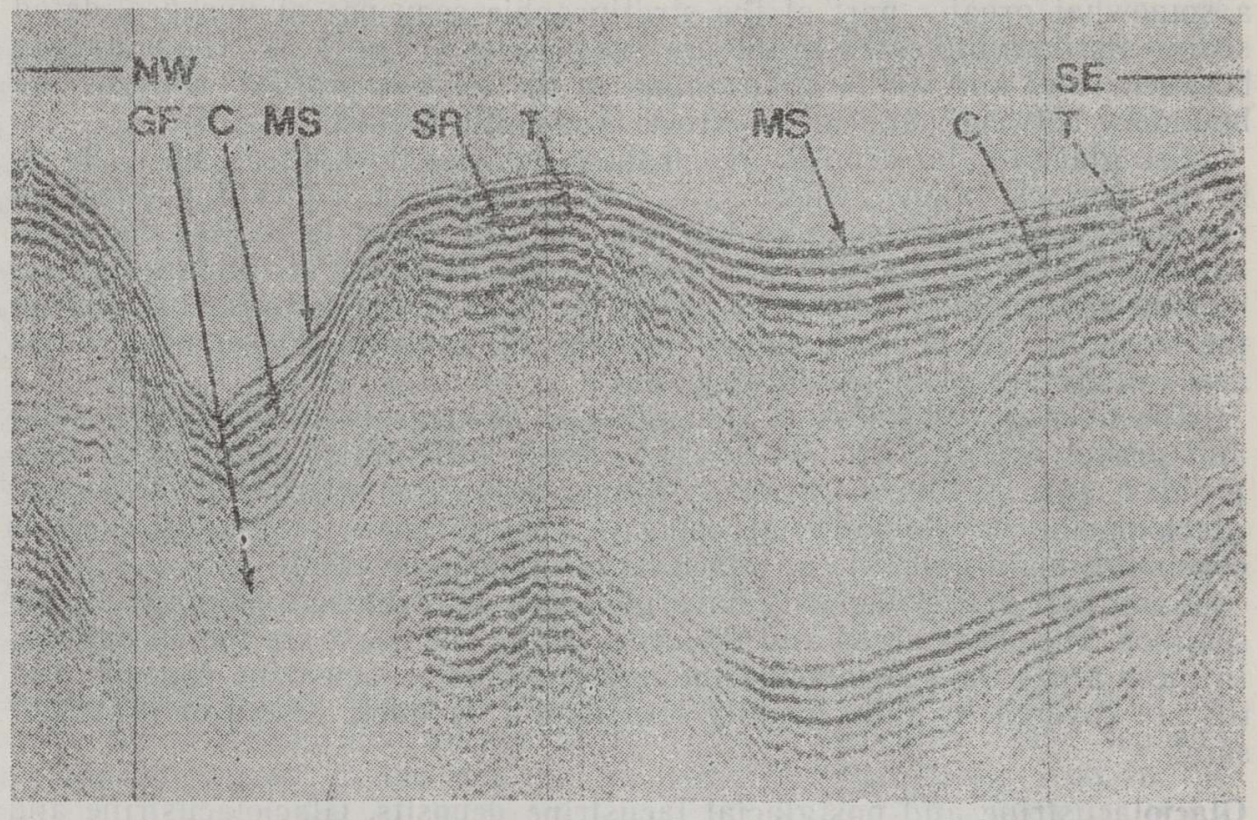

Fig. 6. CSR profile VIII. Glaciolacustrine and postglacial lacustrine clays and marine deposits acting often as "basin fill". The list of seismic marker surfaces and the scale are given in Fig. 3.

The vertical distribution of marine sediments is very extensive. They can be found in the depth interval 25 to $175 \mathrm{~m}$ but, as a rule, they are restricted to depths exceeding $70 \mathrm{~m}$.

The thickness of the marine sediments does not usually exceed $5-7 \mathrm{~m}$ in the areas of flat topography of the subjacent deposits and bedrock. In the nearshore areas of Saaremaa Island, where the inflow of sediments is probably more intensive, the marine sediments are thicker than $7 \mathrm{~m}$. Along the ancient bedrock valleys thicknesses exceeding $10 \mathrm{~m}$ occur; this may be explained by stable sedimentary conditions there.

A map of the Quaternary deposits. The distribution map of the Quaternary deposits (Fig. 2) shows clearly that the glaciolacustrine and postglacial lacustrine deposits crop out on the seafloor over the major part of the investigated area. The outcrops of these deposits are relatively large. In the southern part of the investigated area the outcrops have simple outlines, whereas in the central and northern parts they have more tortuous outlines and a more fragmentary distribution. These differences are obviously due to a more rugged bedrock topography in the areas near the escarpments in the north.

Glaciofluvial gravel and sand deposits have limited outcrops; normally they are covered by younger deposits.

The deposition of Holocene sediments is concentrated to the deeper areas and to the base of the escarpments (Fig. 2). This means that the influence of the bedrock topography on the formation of the deposits has gradually decreased, whereas the influence of the glacial and late-glacial topography has become more pronounced. 


\section{DISCUSSION}

The continuous seismic profiling method used for this investigation makes it possible to differentiate several seismic reflectors in the seabed deposits. However, it may be almost impossible to distinguish the bedrock surface in the areas of thick, boulder-rich glacial drift where considerable scattering of the seismic energy occurs.

The surfaces of the till and glaciofluvial sand and gravel deposits are also normally distinct in the seismic recordings. There are some difficulties in distinguishing these surfaces in the northern part of the investigated area where these deposits partly infill the negative forms of the very rugged topography of the crystalline basement.

The surface of the late- and postglacial lacustrine clays is likewise quite clear. Some areas with a thin $(1-2 \mathrm{~m})$ cover of marine sediments are the exception. In these areas it is difficult to determine the contact between the lacustrine and marine sediments.

The seismic contacts inside the glacial and glaciofluvial deposits are considerably less distinct. Despite this, in some deep ancient valleys it was possible to differentiate $2-3$ seismically different beds of glacial drift, descending probably from different glaciations or different stages of the Weichselian glaciation.

There are several seismic contacts of narrow distribution inside the late- and postglacial deposits. These contacts are probably caused by changes in the lithological composition which are, in turn, caused by crucial changes in sedimentation conditions during the history of the Baltic Sea (Гуделис, 1985). The initial reason for all these changes was the fluctuating climate.

The main features of the structure and distribution of Quaternary deposits are caused predominantly by the bedrock topography, and particularly by the two extensive escarpments and several ancient valleys.

Erosional processes take place over most of the area investigated. Thus, two erosional areas elongated in the NE-SW direction can be distinguished west of Hiiumaa and Saaremaa islands. In these areas till and late- and postglacial lacustrine clays are spread almost equally. The cover of Quaternary deposits is quite uniform $(5-10 \mathrm{~m})$ over these areas. The hills and ridges, made up of till and glaciofluvial deposits, are the only morphological forms, the rest of the seafloor has a relatively flat topography.

Areas of accumulation occur at the base of the escarpments and in the deep ancient valleys, where the thickness of the Quaternary deposits reaches $80 \mathrm{~m}$, and where the stratigraphic sequence of late- and postglacial deposits is the most complete.

Considering that the present seismic profiles were recorded with the intention to study the geological structure of the bedrock, the finest details of the structure of Quaternary deposits have been lost. Despite this, the seismic profiles contain quite adequate data on the structure and distribution of Quaternary deposits.

Unfortunately we have no possibilities to measure the sound velocity in the bottom deposits. The values of sound velocity given by different authors (Mörner et al., 1977; Axberg, 1980) differ considerably. Therefore, the sound velocity values used in the present study may be revaluated in the future, and this may result in a revaluation of the thicknesses of the Quaternary deposits. The changes will, in any case, be rather small.

The seismic data available today are sufficient to distinguish the areas most suitable for sampling and drilling. It is not until cores of good quality are available from the investigated area that the seismic units can be attributed to the conventional stratigraphic units. Despite this we 
can state with certain firmness that glaciolacustrine and postglacial lacustrine clays were deposited during the period which lasted from the Baltic Ice Lake Stage until the end of the Ancylus Lake Stage. The Yoldia Sea Stage was extremely short in this part of the Baltic, about 100 years, and the sediments deposited during this stage cannot be distinguished in the present seismic profiles. Possibly no Yoldia Stage sediments are preserved at all in this area. Future samplings will decide this. Marine sediments have been deposited from the beginning of the Litorina Stage to the present. A similar stratigraphic subdivision of the seismic units, separated in the seismic diagrams, has also been used on the Swedish marine geological maps (Axberg et al., 1988).

The Late Quaternary history of the Baltic Sea is to a great extent the result of fluctuations in climate, which in turn led to the different glaciations, fluctuations in the sealevel, and land uplift. Rather little is known about the Quaternary development of the Baltic before the last glaciation, however.

The ancient valleys and escarpments are the oldest topographic forms that have had a major influence on the location of Quaternary deposits. The development of the valleys possibly started already in the Paleozoic, although they have been transformed later by preglacial fluvial erosion and by the Pleistocene glaciations (Pаукас, 1978).

Considerably more data are available from the Late-Weichselian glaciation. The topographic features of the investigated area are mostly determined by glacial erosion and accumulation. In the ice-marginal zone glaciofluvial deposition took place and deltas and eskers were formed. Despite this no pronounced ice-marginal formations were found in the present area. Later on the sedimentation in local glacial lakes and in the Baltic Ice Lake buried almost all the glacial and glaciofluvial formations. The surface topography of glaciolacustrine clays reflects quite precisely the morphology of the glacial and glaciofluvial deposits. The postglacial lacustrine sedimentation in the Yoldia Sea and the Ancylus Lake filled only partly the depressions in the surface of the glacial and late-glacial deposits. Finally, from the beginning of the Litorina Sea Stage, marine sedimentation takes place and the tendency to level out the seafloor appears to be even more distinct.

The data obtained during the 1991 expedition of R/V Livonia will be analysed more thoroughly in the nearest future and many points of view presented in this paper may be reevaluated and specified. Despite this, the present paper contains the most detailed investigation of the distribution of the seabed deposits west of Hiiumaa and Saaremaa islands performed so far, and it may have some practical application already today.

\section{ACKNOWLEDGEMENTS}

I express my gratitude to Jaan Lutt, Institute of Geology of the Estonian Academy of Sciences, for his helpful comments and discussions during the course of this investigation. I thank Anto Raukas and Väino Puura, both Institute of Geology, Estonian Academy of Sciences, for critical reading and commenting the manuscript. I am also grateful to Tom Flodén and Thomas Andren, both Stockholm University, for valuable comments during the final preparation of this paper. I am especially indebted to Tom Flodén for the possibility to use original seismic recordings and for help in the preparation of figures. Financial support for the project was provided by the Estonian Academy of Sciences, the Swedish Academy of Sciences, and the Stockholm University. 


\section{REFERENCES}

Axberg, S. 1980. Seismic stratigraphy and bedrock geology of the Bothnian Sea, northern Baltic. - Stockholm Contributions in Geology, 36, 153-213.

Axberg, S., Elhammer, A., Kjellin, B, 1988. Maringeologiska kartbladet 099/490 Kopparstenarna, Beskrivning och bilagor. Sweriges Geologiska Undersökning, Uppsala.

Flodén, T. 1980. Seismic stratigraphy and bedrock geology of the central Baltic. - Stockholm Contributions in Geology, 35, 1-240.

Flodén, T. 1981. Current geophysical methods and data processing techniques for marine geological research in Sweden. - Stockholm Contributions in Geology, 37, 4966.

Kjellin, B., Axberg, S., Elhammer, A. 1987. Maringeologiska kartbladet 089/480 Gotska Sandön, Beskrivning och bilagor. Sweriges Geologiska Undersökning, Uppsala.

Lutt, J., Raukas, A. (eds.). 1993. Eesti šelfi geoloogia. Eesti TA, Tallinn.

Mörner, N.-A., Flodén, T., Beskow, B., Elhammer, A. and Haxner, H. 1977. Late Weichselian deglaciation of the Baltic. - Baltica, 6, Acad. Sci. Lithuanian SSR, Vilnius, $33-51$.

Pegrum, R. M. 1989. Course Notes for Basic Seismic Interpretation. Nordisk Ministerrad, $1-152$.

Winterhalter, B. 1972. On the geology of the Bothnian Sea, an epeiric sea that has undergone Pleistocene glaciation. Geological Survey of Finland, Bull. 258, 1-66.

Winterhalter, B. 1975. Sediment deposition, non-deposition and erosion within the northern Baltic Sea region. Underwater 75, Vol. II. Proceedings of the Fourth World Congress of Underwater Activities, Stockholm, 3:15-322.

Winterhalter, B., Flodén, T., Ignatius, H., Axberg, S. and Niemistö, L. 1981. Geology of the Baltic Sea. - In: Voipio, A. (ed.). The Baltic Sea. Elsevier, Amsterdam, 54104 ,

Гуделис В., Емельянов Е. (eds.). 1976. Геология Балтийского моря. Мокслас, Вильнюс, $1-383$.

Гуделис В. (ed.). 1985. Лито- и бностратиграфия донных отложений Балтийского моря. АН Лит. ССР, Вильнюс, $1-205$.

Литвин В., Сагалевич А., Свиридов Н., Шехватов Б. 1974. Строение осадочной толщи и развитие рельефа дна Балтийского моря по данным непрерывного сейсмопрофилирования. Балтика, 5, АН Лит. ССР, Вильнюс, 127-136.

Лутт Я. 1985. Донные осадки Вяйнамери. Валгус, Таллинн, 1-239.

Раукас А. 1978. Плейстоценовые отложения Эстонской ССР. Валгус, Таллинн, $1-310$.

Раукас А., Хюваринен Х. (eds.). 1992. Геология Финского залива. АН Эстонии, Таллинн, $1-422$.

Свиридов Н. 1977. Результаты измерений скорости звука в донных осадках Балтийского моря. Балтика, 6, АН Лит. ССР, Вильнюс, 173-179.

Свиридов Н. 1984. Строение верхней части осадочного чехла Балтийского моря. In: Лисицын A. (ed.). Геологическая история и геохимия Балтийского моря. Наука, Москва, 86-98.

\section{KVATERNAARISETTED EESTI LÄÄNEŠELFIL: SEISMILISE PIDEVPROFILEERIMISE ESIALGSED TULEMUSED}

\section{Riko NOORMETS}

Uks sobivamaid merepõhja ehituse uurimise meetodeid on seismiline pidevprofileerimine, mille tööpõhimõtet ja kasutusvõimalusi on põhjalikult käsitlenud mitmed uurijad (Axberg, 1980; Flodén, 1980, 1981; Pegrum, 1989).

Käesoleva uurimuse aluseks on 1991. aasta kevadsuvel Eesti ja Rootsi ühisekspeditsiooni käigus uurimislaeval «Livonia» kogutud andmed $820 \mathrm{~km}$ seismiliste profiilide kohta Eesti läänešelfilt (joon. 1).

Käsitletava ala pinnakatte struktuuri ja levikut on suuresti mõjutanud aluspõhja pinnamood ja genloogiline ehitus. Oluline on olnud ka neotek- 
tooniliste liikumiste, samuti hilis- ja pärastjääaegsete Läänemere nõos eksisteerinud veekogude transgressioonide ja regressioonide osa.

Kogutud materjali põhjal on pinnakattes võimalik eristada moreeni, liustikujōesetteid (liivad, kruusad), jääjärvede ja pärastjääaegseid järvesetteid (valdavalt peliidid) ja meresetteid (joon. 2). Kasutatud aparatuur võimaldas eristada alad, kus pinnakate merepõhjas puudub või selle paksus on tühine. Aluspõhjakivimite paljandid levivad Hiiumaa ja Saaremaa veealustel nõlvadel ja klindiastangute lähedal. Aluspōhjakivimite ja pinnakatte piir on hästi määratav.

Vahetult aluspõhjal lasub moreen. Viimane on akustilistel profiilidel hästi eristatav ning moodustab kohati koos liustikujõesetetega positiivseid pinnavorme, mille hulgast saab eristada moreenikünkaid, oose ja mõhnu (joon. 3). Esialgse, suhteliselt hõreda uuringuvõrgu tõttu on üksikvormide levikut raske jälgida, kuid siiski on ilmne, et uuritud piirkonnas laialdasi mandrijää servamoodustisi ei kujunenud.

Moreeni paksus on suurim (kuni 40 meetrit) sügavates aluspõhjanõgudes. Ulatuslikel suhteliselt tasastel aladel on selle paksus 5-15 meetrit, kuid klindipealsetel lavamaadel (näiteks Hiiumaast läänes) ja saarte lähemas ümbruses vaid 2-3 meetrit. Paksemates moreenilasundites on mõningatel juhtudel eristatavad $2-3$ seismilistelt omadustelt erinevat kihti ning sel juhul võib tegemist olla näiteks mere poolt hiljem ümbertöötatud ja -setitatud moreenitaoliste setetega või juba algselt vees settinud moreeniainesega, nn. glatsimariinsete setetega (joon. 4).

Liustikujōelised liivad ja kruusad on uuritud alal vähese levikuga. Seda tüüpi setteid leidub järsemate aluspõhjanõlvade jalamitel ning sügavamates aluspõhjanõgudes moreenikihi all, vahekihtidena moreenis, aga ka moreenikihi peal (joon. 5). Liustikujõeliiva paksus on tavaliselt 9-10 meetrit. Suurima paksusega (kuni 25 meetrit) liivalasundid on seotud sügavate aluspõhjanõgudega. Uldjuhul on neis nõgudes ka moreenikihi paksus üle keskmise. Mõnevõrra õhemad on liivalasundid astangute jalamil ning aluspõhja positiivsete pinnavormide nõlvadel. Merepõhjas liiv praktiliselt ei paljandu. Erandiks on rannalähedased ja madalaveelised piirkonnad, kus liiv katab vanemaid setteid õhukese, sageli vähem kui ühe meetri paksuse reliktsette kihina.

Hilis- ja pärastjääaegsete järvesetete paksus on enamasti 5-10 meetrit. Vana reljeefi järsematel nõlvadel ja astangupealsetel on hilis- ja pärastjääaegsete järvesetete kiht märksa õhem või puudub. Tunduvalt paksemalt (kuni 35 meetrit) on järvesetteid astangute jalamil ja sügavates aluspōhja nõgudes, kus need võivad moodustada kuni kolmandiku kvaternaarisetete kogupaksusest. Viimatinimetatud piirkondades ilmneb selgelt savisetete reljeefi tasandav iseloom (joon. 6).

Hilis- ja pärastjääaegsete järvesetete avamused merepõhjas on erineva kuju ja mõõtmetega. Ulatuslikumad ja korrapärasemad neist levivad uuritud ala lounaosas (joon. 2). Piirkonnad, kus savisetted paljanduvad merepõhjas, võivad tänapäeval olla nii kulutuse kui ka episoodilise kuhjumise aladeks.

Meresetete levikualad tähistavad stabiilse nüüdissedimentatsiooniga piirkondi (joon. 2). Uldiselt levivad hilis- ja pärastjääaegsetel järvesetetel lasuvad meresetted astangute jalamil ning Saaremaast ja Hiiumaast läänepool keeruka konfiguratsiooniga vöönditena. Suhteliselt tasase pinnamoega aladel jääb meresetete paksus 5-7 meetri piiridesse. Pikemaajalise pideva settimise ja settematerjali juurdevoolu stabiilsusega on seletatavad kohati rohkem kui 10 meetri paksused meresetete lasundid aluspõhjanõgudes. Kohati on meresetete reljeefi tasandav iseloom isegi teravamalt väljendunud kui hilis- ja pärastjääaegsete setete puhul, kuid harilikult jääb meresetete paksus järvesetetele siiski alla, moodustades kvaternaarisetete kogupaksusest vähem kui veerandi. 


\section{ЧЕТВЕРТИЧНЫЕ ОТЛОЖЕНИЯ БАЛТИНСКОГО МОРЯ \\ ЗАПАДНЕЕ ЭСТОНИИ: \\ ПРЕДВАРИТЕЛЬНЫЕ РЕЗУЛЬТАТЫ СЕЙСИЧЕСКОГО ПРОФИЛИРОВАНИЯ}

\section{Рико НООРМЕТС}

Весной 1991 г. в ходе эстонско-шведской экспедиции на исследовательском судне АН Эстонии «Ливония» было проведено изучение строения морского дна на западном шельфе Әстонии с использованием метода непрерывного сейсмического профилирования как наиболее эффективного для этой цели. На основе 820 км сейсмических профилей составлена карта четвертичных отложений, на которой выделены морена, флювиогляциальные песок и гравий, поздне- и послеледниковые озерные осадки (в основном пелиты) и морские осадки (алевриты, пелиты). Кроме того, обозначены выходы коренных пород на морском дне и показаны характерные сейсмические разрезы, позволяющие получить представление о формах залегания отложений. На фоне относительно ровной поверхности выделяются положительные формы рельефа (моренные холмы, камы и озы), состоящие из моренного и флювиогляциального материала. В пределах изученной акватории краевых ледниковых форм, очевидно, не образовалось. В глубоких долинах, врезающихся в коренной рельеф, местами различаются два или даже три разных по сейсмическим свойствам слоя. По-видимому, в этих случаях в четвертичном разрезе присутствуют моренные слои разного состава или мореноподобные (т. н. глацимаринные) отложения. Более молодые морские осадки накапливались преимущественно в пределах глубоководных участков, а также в отрицательных формах рельефа. При этом на их формирование оказывал определяющее влияние не коренной, а более молодой позднеледниковый рельеф. Таким образом, процесс сглаживания и преобразования коренного рельефа, начавшийся в ледниковое и позднеледниковое время, углублялся и стабилизировался во время послеледникового этапа развития. 